\title{
E-government and corruption perception index: a cross-country study
}

\author{
Christan RA Setyobudi, Dyah Setyaningrum* \\ Accounting Department, Universitas Indonesia, Jakarta, Indonesia \\ *Corresponding Author e-mail: dsetyani@ui.ac.id
}

\section{A R T I C LE IN F O}

\author{
A B S T R A C T
}

Article history:

Available online

Keywords:

e-government; corruption; cross

country studies; transparency

DOI:

https://doi.org/10.20885/jaai.vol23. $\underline{\text { iss1.art2 }}$
The purpose of this study is to analyse the impact of e-government on corruption perception index using a cross-country study. Furthermore, this study aims to examine the most effective e-government components in combating corruption and compare the effects of e-government in developed and developing countries. E-Government is measured using the E-Government Development Index (EGDI), consisting of online services index, human capital index, and telecommunications infrastructure index. The sample for this study consists of 521 observations from 122 countries from 2009 to2013. Our results show that there is a negative effect of e-government implementation towards corruption perception index. Furthermore, based on the elaboration of the e-government component, it was found that the variable infrastructure has a negative effect and the variable human resource dimension a positive effect on corruption perception index. This means that the development of e-government infrastructure can have a significant role in reducing perceptions of corruption in a country, while the dimensions of human resources have a dangerous side that can actually increase perceptions of corruption. There are differences in the effect of e-government on developed and developing countries. In developed countries, the implementation of e-government is in the phase of transaction and transformation which make his impact effective regarding corruption eradication. In developing countries, e-government has only reached the information and interaction phase so that it has not been effective enough to combat corruption.

\section{Introduction}

Corruption is one of the biggest obstacles in economic development, especially in developing countries. Countries that have been severely affected by corruption usually experience economic inefficiency and undetectable environmental exploitation, and the most affected are the poor (UNDP, 2008). Corruption causes development to be not optimal, especially in countries with high economic growth that have potential development lost due to corruption. Government institutions management also become unstable and problematic due to corruption.

In combating corruption, each country carries out various initiatives to continue to improve governance. Among others are the demands for transparency and accountability through access to public information for the community (Cuillier \& Piotrowski, 2009). Transparency also increases trust in government, corruption prevention, quality of decision making, accuracy of government information, and other functions (Bertot et al. 2010). The development of information and communication technology (ICT) that is now underway can support efforts to create transparency and accountability. The application of ICT for public services is referred as e-government. According to Bertot et al. (2010), in recent years, many governments have sought of increasing openness and transparency in their actions. ICT is seen by many as a cost-effective and easy method for realizing openness and transparency and for reducing corruption.

The impact of e-government in eradicating corruption has begun to be investigated by many international organizations. The results are still inconclusive. Previous research has portrayed the success story about role of egovernment in fighting corruption, as evidenced by case studies conducted in South Korea and India (Bhatnagar, 2003). Kim et al. (2009) who analysed the OPEN system in South Korea; or Chawla and Bhatnagar (2004) who analysed BHOOMI, an online system of granting land rights to rural farmers in India. On the other hand, egovernment can be misused by corrupt government employees by learning ways to circumvent e-government systems, using system weaknesses that create room for corrupt behaviour to continue and even grow faster (Bhatnagar, 2003). Heeks (1999) had found that information technology can create new opportunities for corruption of public officials. Thus, e-government can be less successful in combating corruption. 
Lio et al. (2011) have analysed the broad effect of access to internet adoption on reducing corruption. The results of their study state that access to internet adoption can reduce corruption. However, the decline in corruption will be effective if a state has a democratic system and the government has political will to eradicate corruption. Meanwhile, Krishnan et al. (2013) have conducted a study that examined the relationship between the progress of e-government in a country with corruption, economic welfare, and environmental damage. The results of their study state that the progress of e-government has an indirect effect on increasing economic welfare and reducing environmental damage through reduced corruption. Elbahnasawy (2014) empirically had examined the effect of egovernment and the breadth of internet access (number of internet users per 100 inhabitants in each country) on corruption perceptions from 1995 to 2009. There were 160 countries included in his sample consisting of developed and developing countries. The results of his study show that there is a negative effect of e-government and internet use on the level of corruption perceptions, as well as the need for interaction between the two to reduce corruption in a country.

Andersen (2009) had emphasized the need for macro evidence on the effect of e-government on corruption because e-government may be ineffective at the macro level, although micro-level evidence shows its effectiveness in fighting corruption. In the same viewpoint, Ojha et al. (2008) have emphasized the need for empirical research evidence about the effects of e-government on anti-corruption efforts because most existing research tends to be theoretical and descriptive. In addition, even though the United Nations Development Program (UNDP) recently supported e-government as a useful component, it was also stated that much of the evidences linking e-government with a reduction in corruption were not truly reliable because it is based on case studies that are narrow in scope and not facts from empirical research (UNDP, 2006).

To see the extent to which e-government has played a role in eradicating corruption today, this study will extend the one conducted by Elbahnasawy (2014) by investigating the effect of e-government on corruption perceptions with an update of past years research to get an overview of the latest conditions of e-government's role. This study use e-government scores obtained from a United Nation survey known as the E-Government Development Index (EGDI) and corruption perceptions using the Corruption Perception Index (CPI) from 2009 to 2013 based on the Transparency International. CPI surveys public perceptions of the tendency of public servants to do corruption. Based on the above background, the purpose of this study is to provide empirical evidence about the role of e-government in reducing the level of corruption by using cross-country data.

\section{Literature Review}

\section{Agency Theory}

Agency theory is commonly used to explain the agency problem between an agent and a principal, both private and government institutions (Attila, 2012). In government institutions, principals are elected public officials who are responsible for various forms of services to the public. In order to carry out this responsibility they appoint agents namely civil servants or bureaucrats who served the community. Agency problems arise when agents take advantage of the power entrusted to them to meet their own needs or meet certain party needs. They exploit their position to act according to their own desires through bribery, embezzlement, fraud, nepotism and extortion (Lio et al., 2011).

Corruption is defined by the Association of Certified Fraud Examiners (ACFE) as an abuse of power by violating obligations with the aim of obtaining benefits both directly and indirectly. Klitgaard (1988) developed a formula of corruption in which corruption is the same as monopoly access to information (monopoly) coupled with the freedom to use that information (discretion) reduced by a system of accountability and supervision, which when arranged in the equation becomes: $\mathrm{C}=\mathrm{M}+\mathrm{D}-\mathrm{A}$. This means that the increased ability of bureaucrats to manage information and act arbitrarily on the information will increase corruption rate, while a decline in the system of accountability and supervision by superiors and the public will also increase corruption. Corruption can reduce economic growth by reducing investment; distorting government spending and allocation of resources; weaken public institutions and law enforcement; reduce income distribution; direct expert human resources to carry out rent-seeking activities; and increasing economic inefficiency, policy uncertainty, and political instability (Elbahnasawy, 2014). E-government can be defined as the use and application of information technology in public administration to streamline and combine workflows and processes, to effectively manage data and information, improve the quality of public services, and also develop communication channels for citizen involvement and empowerment (United Nations, 2014). E-government is a means of increasing efficiency and transparency in the implementation of transactions involving internal government, government to citizen, government to business, government to government, and government to employees. 


\section{Hypothesis Formulation}

Shim and Eom (2009) have stated that anti-corruption approaches usually consist of three important factors: administrative reform, law enforcement, and social change. According to Bertot et al. (2010) the information delivery to citizens and the ability of citizens to oversee government activities play an important role. E-government and other forms of ICT can be used to fight corruption. Cultural influences often make social change the biggest challenge in realizing openness and anti-corruption initiatives. E-government is expected to bridge this cultural influences, where the corruption eradication does not only focus on efforts to reduce the discretionary and monopolistic power of bureaucrats (through e-procurement procurement systems and transactions where conditions are made as fair as possible for all parties), but also involving citizens and raises a culture of transparency and public supervision (through government sites and interactive applications that can monitor the performance of bureaucrats). Many countries with laws on transparency have directly linked the implementation of these regulations to the implementation of ICT-based initiatives, usually through e-government (Relly \& Sabharwal, 2009).

Elbahnasawy (2014) had stated that widespread internet access for citizens, along with the application of an increasingly advanced e-government system, is a powerful tool to combat corruption. The EGDI survey conducted by the United Nations discussed about three dimensions that support the achievement of the maximum function of e-government in a country. These three dimensions are (1) online services; (2) telecommunications infrastructure; and (3) the capacity of human resources that run it. The high quality of online services increases transparency and access to public information. The public also increasingly has the power to influence public policy and become a whistle-blower as a form of control if there are government actions that are considered odd. This will be even more effective when online complaints media are also developing. The more advanced telecommunications infrastructure the more will expand the scope of e-government in making an impact on corruption perceptions. Weak infrastructure causes the implementation phase of e-government to only reach the information phase and the interaction phase, where e-government only takes the form of local government sites and other forms of online presence. Conversely, good infrastructure can lead to the achievement of the transaction and transformation phase, such as when e-procurement successfully prevents direct interaction between parties in the procurement auction. A successful example in this case is the OPEN system that successfully engages the community in tracking the work of bureaucrats (Kim et al., 2009). The quality of human resources as an operator is also important in supporting the development of e-government. The progress of infrastructure and information becomes less useful if the bureaucrats who run e-government are incompetent and instead become obstacles that cause services to the public to be slower. Well competent human resources who understand the ins and outs of egovernment will make it easier for citizens to use public services. Therefore, the hypothesis in this study is:

H1: The application of e-government has a negative effect on corruption perceptions

\section{Research Method}

\section{Data Collection Method and Sample Selection}

The type of data used in this study is secondary data. The unit's analysis are countries in the world surveyed by the United Nations to obtain both the EGDI index and Transparency International to obtain the Corruption Perception Index from 2009-2013, it's cross-section data, although the data collection is carried out for 5 years period. This is because in this study it is assumed that there are no inter-year relationships. The data we used are unbalanced because some country does not have complete set of data every year.

\section{Research Model}

This study uses the Ordinary Least Square (OLS) estimation method. This method was also used by Andersen (2009) in measuring the effectiveness of e-government in fighting corruption. The model in this study refer to Elbahnasawy (2014).

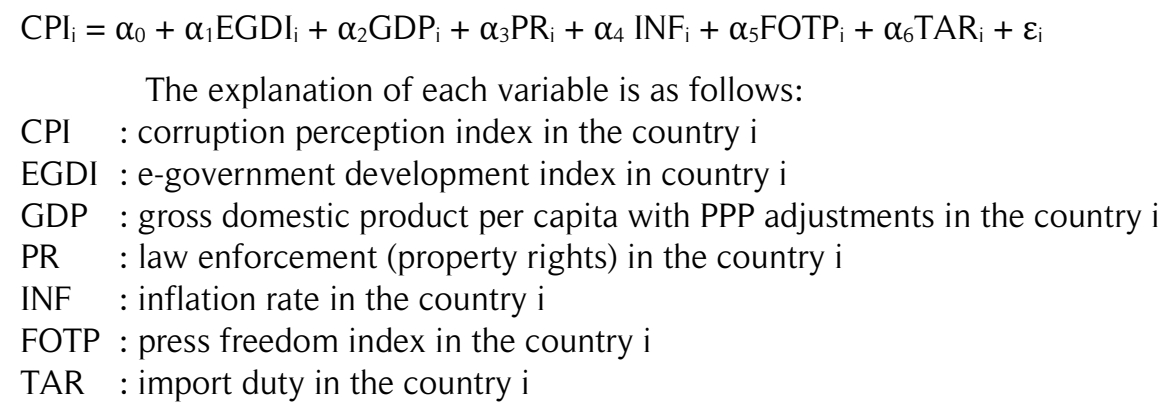




\section{Variable Operationalization}

The dependent variable in this study is the corruption perception index (CPI). CPI has been widely used for research on corruption because of its broadest coverage, most consistently carried out periodically, and represent the condition of the level of corruption in a country's bureaucracy. Previous research using this index includes Treisman (2000), Svensson (2005), Andersen (2009), Lio et al. (2011), Liu and Lin (2012), and Elbahnasawy (2014). This variable is measured by transposing the Corruption Perception Index (CPI) value obtained from the Transparency International (TI) survey from 2009 to 2013. The index scale is 0 to 10 , where 0 means the country is perceived to be a very corrupt one, while 10 means that the country is perceived to be very clean one. To facilitate understanding and adjust to existing hypotheses and in accordance with Elbahnasawy's research (2014), the CPI number of each country was reversed so that 10 means the state is perceived as a very corrupt and number 0 means that the state is perceived as a very clean.

The independent variable in this study is the e-government implementation. Based on the EGDI survey, advanced applications of e-government were given high scores and those who were still not advanced was given a low score. The EGDI is a comprehensive measurement of the willingness and capacity of a country's bureaucracy to use information and communication technology in carrying out government functions (Elbahnasawy, 2014) . The EGDI is an average index of three components, namely: (1) online service index (OSI); (2) telecommunications infrastructure index (TII); and (3) human capacity index (HCI). The OSI assesses the level of freedom of access from the contents of government sites in each country in accordance with the guidelines drawn up by the United Nations on information needed in government websites. The OSI seeks to take into account the level of maturity of ICT services of a country that can be classified into four phases, namely the information phase, the interaction phase, the transaction phase, and the transformation phase. The TII is measured based by five indicators: (1) number of computers (PC); (2) number of internet users; (3) telephone network; (4) users of mobile telephone services; and (5) number of broadband internet customers. Each variable is measured per 100 populations. Finally, the $\mathrm{HCI}$ consists of a literacy rate and gross enrolment ratio for primary, secondary and tertiary education (United Nations, 2010).

The first control variable is GDP per capita. Elbahnasawy and Revier (2012) have concluded that GDP per capita is one of the determinants of corruption that has proven to be always strong and often used in various empirical studies regarding factors that affect corruption. Wealthier countries usually have more ability to fight corruption, because of greater allocation of resources and provision of more advanced education. Therefore, poorer countries are perceived as more corrupt than wealth countries. In other words, GDP per capita has a negative effect on corruption perceptions according to Elbahnasawy and Revier (2012). Data on GDP per capita were obtained from the World Development Indicators owned by the World Bank by using constant purchasing power parity (PPP) adjustments in US dollars as used by Elbahnasawy (2014).

The second control variable is law enforcement. Elbahnasawy and Revier (2012) have found that law enforcement is a prerequisite for effective corruption eradication, where when law enforcement goes well, all corruption practices detected will be more quickly dealt with and addressed. Moreover, strong law enforcement will weaken the bureaucrat's drive to act corruptly. Law enforcement also has a negative effect on the corruption perception. Elbahnasawy (2014) have used the index property-rights (PR) data from the Heritage Foundation to measure law enforcement. This index measures how capable a law in a country protects private property rights and how far the government enforces the law. This index also analyses the independence of law enforcers, the existence of corruption in the judiciary, and the ability of individuals and businesses to comply with the rules of the agreement prepared. This index score has a range scale of 0-100, where higher scores state greater capacity for legal protection in a country.

The inflation rate is the third control variable. The inflation rate is widely used to predict the level of corruption in a country. Treisman (2007) had said that a higher and more volatile inflation would lead to increasingly difficult supervision of government spending and public contracts. And because of this matter, countries with higher inflation rates also tend to have a higher level of corruption. In other words, the inflation rate has a positive effect on the level of perceptions of corruption. Data for inflation in this study was obtained from the International Monetary Fund (IMF) which issued a database describing the economic conditions of world countries by the name of the World Economic Outlook (WEO) database.

Freedom of the press is the fourth control variable. Freille et al. (2007), Kolstad and Wiig (2009) and Treisman (2007) are researchers who support the importance of press freedom in combating corruption. The existence of press freedom is important in providing space for e-government to fight corruption. Transparency created by press freedom supports the implementation of e-government as a manifestation of the government's efforts to be more transparent. Elbahnasawy (2014) had used data from Freedom House which has compiled an index of freedom of the press (FOTP) since 1980 that gave ratings on countries around the world based on the level 
of freedom obtained by the press in their country to explore and convey information. The index scale is $0-100$, where 100 is a condition when a country experiences the highest supervision of the press, while 0 is a condition when press freedom is the most highly respected. To be aligned with the hypothesis, this study transposes the FOTP index value, where a high FOTP index indicates a high level of press freedom (and vice versa). The higher the freedom of the press the lower the level of corruption in a country. In other words, freedom of the press has a negative effect on the corruption perception.

The last control variable is openness measured using import duty. Treisman (2007) expressed the importance of openness to international trade as one of the factors that can predict the level of corruption. With market openness, competition in the market will increase, and therefore reduce rent-seeking behaviour by bureaucrats by reducing the monopoly power of local producers. Dutt (2009) had found that protectionist policies would lead to higher corruption, because overly strict regulation of international trade would lead to increasingly thick bureaucracy which created a gap for corruption by bureaucrats, as well as the possibility of a monopoly by local entrepreneurs who already understand the way of workings of bureaucrats. Treisman (2007) had used the percentage imports value to GDP as a measurement of market openness in a country. Elbahnasawy (2014) had used a direct measure of trade protectionism in a country, namely import duty on goods, with data sources from World Development Indicators from the World Bank. Our study followed the one of Elbahnasawy (2014) by using the import duty rates. The hypothesis is that the higher the protection made by a country towards market freedom, the higher the corruption perception. In other words, import duties have a positive effect on the corruption perception.

This research also conducts two additional testing. The first additional test is to examine which dimensions of e-government have a strong effect on corruption perception. The three main dimensions of EGDI, namely the Online Service Index (OSI), the Telecommunication Infrastructure Index (TII), and the Human Capital Index (HCI) was tested separately toward corruption perception. The second additional test was performed by separating sample into two sub sample developed and developing countries and then test whether the implementation of egovernment in the two different groups has different effects on corruption.

\section{Results and Discussion}

\section{Statistics Descriptive}

Based on the sample selection method, there were 170 countries surveyed both by Transparency International and the United Nation to get the scores of the CPI and EGDI index. Among the 170 countries, countries with complete data were chosen. The final selection results show the number of samples worth 521 (unbalanced data panels). The results of descriptive statistics for each variable are shown in Table 1.

Table 1. Statistics Descriptive Variables

\begin{tabular}{lrrrrrr}
\hline \multicolumn{1}{c}{ Variable } & $\mathrm{N}$ & \multicolumn{1}{c}{ Mean } & \multicolumn{1}{c}{ Std Dev } & \multicolumn{1}{c}{ Min } & \multicolumn{1}{c}{ Median } \\
\hline CPI & 521 & 5,441 & 2.152 & 0.6 & 6.2 & 8.4 \\
EGDI & 521 & 0.519 & 0.214 & 0.047 & 0.524 & 0.912 \\
GDP $(\$)$ & 521 & 19354.5 & 19930.5 & 657.4 & 13327.8 & 127819 \\
PR & 521 & 48,695 & 24,739 & 0 & 40 & 95 \\
INF & 521 & 0.048 & 0.074 & $-0,064$ & 0.034 & 1,087 \\
FOTP & 521 & 55,516 & 22,516 & 5 & 56 & 90 \\
TAR & 521 & 0.045 & 0.039 & 0 & 0.034 & 0.177 \\
\hline
\end{tabular}

CPI: corruption perception index; EGDI: E-government Development Index; GDP: Gross Domestic Product per capita with PPP adjustment; PR: Property Right; INF: Inflation Rate; FOTP: Freedom of The Press; TAR: Import Duty Tariff

The descriptive statistics show several important findings, including: (1) the average perception level of corruption (CPI) in the sample countries is quite high at 5.44 above the median value of 5; and (2) the mean and median of the EGDI are in the range of 0.52 which means that generally the level of implementation of egovernment is still at the middle level, but the trend over the past 5 years shows an increase from year to year.

\section{Hypothesis Testing}

The Ordinary Least Square (OLS) is used to test hypothesis. The regression results are shown in Table 2. 
Table 2. Regression Results

\begin{tabular}{lclll}
\hline Variable & Prediction Sign & Coefficient & P-value & Significance \\
\hline EGDI & - & -0.416 & 0.081 & $*$ \\
GDP & - & $-0,000$ & 0,000 & $* * *$ \\
PR & - & $-0,064$ & 0,000 & $* * *$ \\
INF & + & 0.004 & 0.496 & Not significant \\
FOTP & - & -0.006 & 0.009 & $* * *$ \\
TAR & + & 1,578 & 0.091 & $*$ \\
Observation: 521 & & Prob>F $=0.0000$ & & $\mathrm{R}^{2}=0.8957$ \\
\hline
\end{tabular}

*: significant at $\alpha=10 \%$;** significant at $\alpha=5 \%$; **: significant at $\alpha=1 \%$. CPI: corruption perception index; EGDI: Egovernment Development Index; GDP: Gross Domestic Product per capita with PPP adjustment; PR: Property Right; INF: Inflation Rate; FOTP: Freedom of The Press; TAR: Import Duty Tariff.

The regression results indicate that the e-government (EGDI) has a negative effect on the dependent variable perception of corruption (CPI) with $90 \%$ confidence level. This is consistent with the findings of Andersen (2009) and Elbahnasawy (2014) which mentioned the importance of using e-government as a product of technological developments to increase transparency and help anti-corruption movement initiatives. This is also in line with the findings of Lio et al. (2011) who evaluated the magnitude impact of technological progress and internet use on the efforts to eradicate corruption. E-government is a concrete implementation of the internet use. Therefore, it can be concluded that advancement technological progress and greater awareness of the importance of public transparency, will led to the increasingly crucial role of e-government to eradicate corruption (Bertot et al., 2010).

Gross domestic product (GDP), law enforcement (PR), and freedom of the press (FOTP) have a significant negative effect on corruption perceptions at a $99 \%$ confidence level. Furthermore, the variable import duty tariff (TAR) has positive effect on the corruption perception at the $90 \%$ confidence level, while inflation (INF) does not affect significant effect. The results of this study confirm the importance of e-government collaborating with other corruption determinant factors in supporting the creation of corruption-free government administration. Law enforcement, press freedom, and good import duty can represent a culture of openness and transparency in a country. Openness and transparency are important to create awareness of bureaucrats to work responsibly because they are supervisors and the law will protect those who supervise. Meanwhile, high GDP can also reduce corruption when a country's economic progress can be directed correctly for infrastructure development and anti-corruption initiatives.

To see further which dimensions of e-government has an effect on corruption eradication, additional testing was carried out using all three e-government dimensions, namely the dimensions of online service quality (OSI), human resource dimensions ( $\mathrm{HCl}$ ), and telecommunications infrastructure dimensions (TII) as shown in Table 3.

Table 3. Regression Results of E-Government Dimensions

\begin{tabular}{lcllc}
\hline Variable & Prediction Sign & Coefficient & P-value & Significance \\
\hline OSI & - & $-0,022$ & 0.462 & Not significant \\
HCI & - & 0.862 & 0,000 & $* * *$ \\
TII & - & $-1,349$ & 0,000 & $* * *$ \\
GDP & - & $-0,000$ & 0,000 & $* * *$ \\
PR & - & $-0,063$ & 0,000 & $* * *$ \\
INF & + & -0.004 & 0.459 & Not significant \\
FOTP & - & -0.004 & 0.043 & $*$ \\
TAR & + & 2,221 & 0.030 & $\mathrm{R}^{2}=0.9018$ \\
Observation: 521 & & Prob> F $=0.0000$ & & $*$. \\
\hline
\end{tabular}

*: significant at $\alpha=10 \%$; ${ }^{* *}$ : significant at $\alpha=5 \%$; **: significant at $\alpha=1 \%$. CPI: corruption perception index; EGDI: Egovernment Development Index; GDP: Gross Domestic Product per capita with PPP adjustment; PR: Property Right; INF: Inflation Rate; FOTP: Freedom of The Press; TAR: Import Duty Tariff

The online service quality index (OSI) variable has no relationship with CPI. This mean that the implementation of an online service system may be less useful without the quality of human resources, which has adequate intelligence but also has strong ethics. It can be interpreted that the progress of the quality of online services will still fail to realize full transparency if misused by human resources with bad intentions. Moreover, the 
society is still less involved in using an e-government system due to lack of information. From this it can be seen the importance of the quality of human resources not only to e-government bureaucrats and workers, but also to the communities to which e-government is directed. Moreover, in a higher e-government phase (the transaction phase and transformation phase) it is demanded that deeper community involvement, both when interacting with the government and becoming agents of change itself. This result can also indicate that the degree of implementation of e-government in each country is different. The degree of implementation in question is the four phases delivered by Maio and Baum (2000), namely the information, interaction, transaction and transformation phases. It is possible that in many countries, especially developing ones, the implementation of e-government has only reached the first or the second phase (information and interaction) so that the quality of online services does not have much effect.

The positive effect of human resources index $(\mathrm{HCl})$ on corruption perceptions confirms the UNDP (2008) study which is concerned about the misuse of e-government by authorized officials or bureaucrats who control the system. The high quality of human resource intelligence that runs e-government does not mean strengthening corruption eradication. It can be estimated that this is because measurements in the $\mathrm{HCl}$ dimension only pay attention to intelligence matters such as the quality of education and the level of literacy, but pay little attention to aspects such as ethics and honesty. One possibility is that the high quality of human resource education without being followed by good compass moral from e-government workers can lead to a system that only benefits some parties and even causes the failure of public transparency.

Meanwhile, the telecommunications infrastructure index has a negative effect on the corruption perception. This is in accordance with the findings of Elbahnasawy (2014), showing that telecommunications infrastructure is indeed important in supporting a corruption-free system. Without adequate infrastructure, it would be very difficult to develop a comprehensive and truly functioning e-government system in serving the community. As with infrastructure in other sectors, the government also needs to understand the importance of infrastructure in the telecommunications sector, because this can strengthen the e-government system that helps eradicate corruption. The results of this study support the continued increase of investment in infrastructure in order to create broader government transparency. This is especially important for developing countries that are still in the low implementation phase, where the e-government system that is owned has not been able to have enough impact in fighting corruption.

\section{Additional Test}

The purpose of the second additional test is to investigate whether there are differences in the effect of egovernment implementation on corruption perceptions in developed and developing countries. The sample countries were divided into developed and developing countries according to World Bank guidelines. Of the 521 observations, the number of developed countries were 189 observations and 332 observations for developing countries. The results of testing using developed country can be seen in Table 4, while for developing countries in Table 5. The regression results of the two groups of countries turned out to be different. In developed countries the EGDI has a significant negative effect on the CPI, while in developing countries the EGDI does not have a significant effect on the CPI.

Table 4. Regression Results of Developed Countries Sample

\begin{tabular}{lclll}
\hline Variable & Prediction Sign & Coefficient & P-value & Significance \\
\hline EGDI & - & -0.898 & 0.003 & $* * *$ \\
GDP & - & $-0,000$ & 0.001 & $* * *$ \\
PR & - & -0.083 & 0,000 & $* * *$ \\
INF & + & 2,978 & 0.157 & Not significant \\
FOTP & - & -0.004 & 0.165 & Not significant \\
TAR & + & 1.955 & 0.343 & Not significant \\
Observation: 189 & & Prob> F $=0.0000$ & & $\mathrm{R}^{2}=0.8429$ \\
\hline
\end{tabular}

*: significant at $\alpha=10 \%$; **: significant at $\alpha=5 \%$; *** significant at $\alpha=1 \%$. CPI: corruption perception index; EGDI: Egovernment Development Index; GDP: Gross Domestic Product per capita with PPP adjustment; PR: Property Right; INF: Inflation Rate; FOTP: Freedom of The Press; TAR: Import Duty Tariff

The e-government implementation in developed countries had a significant effect in reducing perceptions of corruption. In the developed countries, people have an awareness of transparency and accountability and an awareness of the use of ICT advancements to further strengthen transparency. It appears that in developed 
countries, they implement high-level e-government (transaction and transformational phase) that has a real impact in efforts to eradicate corruption. From this, an understanding can be taken that developed countries need to spread the spirit of transparency by providing support to e-government systems in developing countries so that the impact of e-government in fighting corruption can be more widely felt.

Table 5. Regression Result in Developing Countries

\begin{tabular}{lclll}
\hline Variable & Prediction Sign & Coefficient & P-value & Significance \\
\hline EGDI & - & -0.352 & 0.210 & Not significant \\
GDP & - & $-0,000$ & 0.003 & $* * *$ \\
PR & - & -0.049 & 0,000 & $* * *$ \\
INF & + & 0.192 & 0.317 & Not significant \\
FOTP & - & -0.009 & 0000 & $* * *$ \\
TAR & + & 2.611 & 0.009 & $* * *$ \\
Observation: 332 & & Prob> F $=0.0000$ & & $\mathrm{R}^{2}=0.6899$ \\
\hline : & & &
\end{tabular}

*: significant at $\alpha=10 \%$; $*$ : significant at $\alpha=5 \%$; **: significant at $\alpha=1 \%$. CPI: corruption perception index; EGDI: E-government Development Index; GDP: Gross Domestic Product per capita with PPP adjustment; PR: Property Right; INF: Inflation Rate; FOTP: Freedom of The Press; TAR: Import Duty Tariff

The insignificant effect of e-government on the corruption perception in developing countries is in accordance with Bhatnagar (2003) and the UNDP (2008). It could be caused by the misuse of e-government by corrupt employees. In addition, this result can also be caused by the minimum conditions that must be met so that the utilization of information technology can reduce corruption that has not been achieved. Lio et al. (2011) have said that the minimum conditions that must be fulfilled include a strong democratic system, political will and sense of crisis to eradicate corruption. In addition, it can be concluded that e-government that has only reached the low phase (information and interaction phases) and that has not been useful for fighting corruption, especially in developing countries where the culture of corruption is quite entrenched. Transparency International (2014) has stated that two-thirds of countries in the world have poor CPI values. For this reason, efforts need to be made to continue to advance e-government in developing countries and investment assistance from developed countries so that e-government can be more beneficial in fighting corruption.

\section{Conclusion}

Based on the testing and discussion, there are three important conclusions that can be driven from this study. First, the adoption of e-government has a significant negative effect on the level of perceptions of corruption. This indicates that e-government can be a powerful tool to help fight corruption. Secondly, based on the elaboration of the e-government dimensions, it was found that the human resource $(\mathrm{HCl})$ dimension had a positive effect and infrastructure (TII) had a negative effect on the implementation of e-government. This means that the development of e-government infrastructure can have a significant role in reducing perceptions of corruption in a country, while the dimensions of human resources that run well have a dangerous side that can actually increase perceptions of corruption. Meanwhile the aspect of online service quality (OSI) is not significant. Third, there are differences in the effect of e-government on developed and developing countries. In developed countries, the implementation of e-government is in the phase of transaction and transformation so that it has a real impact in efforts to eradicate corruption. In developing countries, e-government has only reached the information and interaction phase so that it has not been effective enough in fighting corruption.

The implication of the results of this study especially in developing countries is that governments are developing strategies for the implementation of ICTs in assisting their administration. With the awareness of the importance of the role of ICT in combating corruption, this can further strengthen the role of management and accounting information systems in the government. The government must increase transparency commitments and invest more in the e-government sector. In addition, from a more in-depth analysis of which of the three dimensions of the EGDI are more influential, it can be noted that the importance of developing infrastructure and good education for human resources that execute e-government systems to optimize the e-government functions. Government investment especially in developing countries can be focused on improving telecommunications infrastructure. On the other hand, state officials and bureaucrats who run an e-government system need to enforce a stronger code of ethics so that the initial functions of e-government are not distorted, utilized, or misused by those responsible. 
There are several limitations and suggestions given from this research that need to be developed in future studies. First, this study has not included all control variables between countries, such as cultural level, level of governance. Subsequent research can classify countries according to cultural contexts (through regional based classification), classification according to level of governance (division between OECD and non-OECD countries), or classification according to economic conditions (such as classification by GDP). Second, this study uses the egovernment index using secondary data, further research can consider building instruments that are more suitable for measuring variables and using primary data through questionnaires or scoring. Third, it is necessary to consider testing the two-way causality relationship between corruption and e-government. Fourth, research can be developed by classifying the phases of e-government implementation in each country then each country would be classified according to the four phases. This classification can further explain how far e-government helps eradicate corruption.

\section{References}

Andersen, T. B. (2009). E-Government as an anti-corruption strategy. Information Economics and Policy, 21(3), 201-210.

Association of Certified Fraud Examiners (ACFE). (2012). Report to The Nations on Occupational Fraud and Abuse. Austin.

Attila, G. (2012). Agency Problems In Public Sector. Annals of Faculty of Economics, 1(1), 708-712.

Bertot, J. C., Jaeger, P. T., \& Grimes, J. M. (2010). Using ICTs to create a culture of transparency: E-government and social media as openness and anti-corruption tools for societies. Government Information Quarterly, 27(3), 264-271.

Bhatnagar, S. (2003). E-government and access to information.

Chawla, R., \& Bhatnagar, S. (2004). Online delivery of land titles to rural farmers in karnataka, India. In Scaling Up Poverty Reduction (pp. 1-25). Shanghai: World Bank.

Cuillier, D., \& J.Piotrowski, S. (2009). Internet information-seeking and its relation to support for access to government records. Government Information Quarterly, 26(3), 441-449.

Dutt, P. (2009). Trade Protection and Bureaucratic Corruption: An Empirical Investigation. Canadian Journal of Economics, 42(1), 155-183.

Elbahnasawy, N. G. (2014). E-government, internet adoption, and corruption: An empirical investigation. World Development, 57, 114-126.

Elbahnasawy, N. G., \& Revier, C. F. (2012). The determinants of corruption: Cross-country-panel-data analysis. The Developing Economics, 50(4), 311-333.

Freille, S., Haque, M. E., \& Kneller, R. (2007). A contribution to the empirics of press freedom and corruption. European Journal of Political Economy, 23(4), 838-862.

Heeks, R. (1999). Information Technology and the Management of Corruption. Development in Practice, 9(1/2), 184-189.

Kim, S., Kim, H. J., \& Lee, H. (2009). An institutional analysis of an e-government system for anti-corruption: The case of OPEN. Government Information Quarterly, 26(1), 42-50.

Klitgaard, R. (1988). Controlling Corruption. California: University of California Press.

Kolstad, I., \& Wiig, A. (2009). Is transparency the key to reducing corruption in resource-rich countries? World Development, 37(3), 521-532.

Krishnan, S., Thompson, S. . T., \& Lim, V. K. G. (2013). Examining the relationships among e-government maturity, corruption, economic prosperity and environmental degradation: A cross-country analysis. Information \& Management, 50(8), 638-649.

Lio, M.-C., Liu, M.-C., \& Ou, Y.-P. (2011). Can the internet reduce corruption? A cross-country study based on dynamic panel data models. Government Information Quarterly, 28(1), 47-53.

Liu, J., \& Lin, B. (2012). Government auditing and corruption control: Evidence from China's provincial panel data. 
China Journal of Accounting Research, 5(2), 163-186.

Maio, A. Di, \& Baum, C. H. (2000). Gartner's Four Phases of E-Government Model. Stamford: Gartner Group Inc.

Ojha, A., Palvia, S., \& Gupta, M. P. (2008). A model for impact of e-government on corruption: Exploring theoretical foundations. In J. Bhattacharya (Ed.), Critical Thinking in E-Governance (pp. 160-170). New Delhi: GIFT Publishing.

Relly, J. E., \& Sabharwal, M. (2009). Perceptions of transparency of government policymaking: A cross-national study. Government Information Quarterly, 26(1), 148-157.

Shim, D. C., \& Eom, T. H. (2009). Anticorruption effects of information communication and technology (ICT) and social capital. International Review of Administrative Sciences, 75(1), 2009.

Svensson, J. (2005). Eight questions about corruption. Journal of Economic Perspectives, 19(3), 19-42.

Transparency International Secretariat. (2014). Corruption Perceptions Index 2014: Clean Growth At Risk. Retrieved from https://www.transparency.org/news/pressrelease/corruption_perceptions_index_2014_clean_growth_at_risk

Treisman, D. (2000). The causes of corruption: a cross-national study. Journal of Public Economics, 76(3), 399457.

. (2007). What have we learned about the causes of corruption from ten years of cross-national empirical research? Annual Review of Political Science, 10, 211-244.

United Nations. (2010). United Nations E-Government Survey 2010. New York: UN Publishing Section. . (2014). United Nations E-government Survey 2014. New York: United Nation.

United Nations Development Program. (2006). Fighting Corruption with e-Government Applications. New York. Retrieved from http://unpan1.un.org/intradoc/groups/public/documents/un-dpadm/unpan043296.pdf . (2008). Tackling Corruption, Transforming Lives: Accelerating Human Development in Asia and the Pacific. New Delhi. 